\title{
Consumer Background and Decision Making Styles of Malaysian College Students
}

\author{
Sharifah Azizah Haron ${ }^{1} \&$ Anyanwu Hilary Chinedu ${ }^{2}$ \\ ${ }^{1}$ Malaysian Research Institute on Ageing (MyAgeing), Universiti Putra Malaysia, Malaysia \\ ${ }^{1,2}$ Department of Resource Management and Consumer Studies, Faculty of Human Ecology, Universiti Putra \\ Malaysia, Malaysia \\ Correspondence: Sharifah Azizah Haron, Malaysian Research Institute on Ageing (MyAgeing), Universiti Putra \\ Malaysia, 43400 UPM Serdang, Selangor, Malaysia. E-mail: sh.azizah@upm.edu.my
}

Received: November 2, 2017

doi:10.5539/ijbm.v13n1p170
Accepted: December 8, 2017 Online Published: December 20, 2017

URL: https://doi.org/10.5539/ijbm.v13n1p170

\begin{abstract}
This study tested a section of consumer styles inventory (CSI) among Malaysian college students. Using stratified and simple random sampling, 2068 samples were collected from five higher learning institutions in Klang Valley, Malaysia. The study extracted seven factors through exploratory factor analysis from the original CSI scale which was found reliable and useful to consumer markets. Gender, age, ethnicity, family size, household income and place where a student was raised were found to have significant influence on the CSI factors. The findings will be a guide for markets facing competitive pressures by guiding them on the appropriate market segmentation. In addition, firms should focus on the influential background variables during new product designs in order to get the target markets' preferences and balance their competitive pressures simultaneously.
\end{abstract}

Keywords: Consumer style inventory, Malaysian college students, shopping decision making, market segments

\section{Introduction}

Consumer decision-making styles (CDMS) profiles are consistent over a course of time and linked to individual shopping behavior. For example, Bae et al. (2009) found that CDMS were found influential to consumer shopping behavior for sports products and other essential commodities. Hence, for marketers, CDMS is useful for segmenting the market (Walsh, Hennig-Thurau, Mitchell, \& Wiedmann, 2001), while consumer educationists may use it as a guide to inculcate responsible actions into consumers. Given the importance of CDMS to various parties, researchers have devoted more time to unmask the underlying factors in identifying the profile of certain market segments. Previous literatures centered on identifying general decision making styles (e.g. Walsh, Mitchell, \& Hennig-Thurau (2001) and Tai (2005).

Evidence shows that CDMS vary across cultures (Walsh, Mitchell and Hennig-Thurau, 2001). Thus, there is no single accepted decision-making typology to date (Mitchell and Bates, 1998) despite the existence of decision making multiple theories (e.g: cue utilization theory and Nicosia's model of buyer behavior) and consumer typologies (e.g: consuming as play and consuming as classification) which are mostly based on Sproles and Kendall (1986) Consumer Style Inventory (CSI). The generalizability of CSI was tested across different cultures such as Korea (Hafstrom, Chae, \& Chung, 1992); China (Fan \& Xiao, 1998; Hiu et al., 2001) and Germany (Walsh et al., 2001). In Malaysia, CSI study was conducted among others by Wan Omar et al. (2009) and Mokhlis (2009). Several researchers concluded that CDMS differs across cultures and that the original form of CSI needs to be re-examined in different countries' contexts and cannot be generalized to the whole world.

Undoubtedly, the influence of demographic variables on CSI components in Malaysian context had not received substantive attention, as such; it should be well studied due to college students' changing tastes, preferences, demographic and environmental changes. Though some published studies (Mudahi et al., 2012; Mokhlis, 2009; Wan Omar et al., 2009; Othman, Ong, \& Wong, 2008) on consumer decision-making styles in Malaysia provided an insight into consumer behavior within a specific context, they came short of investigating the role of demographic variables on each CSI component. In addition, a section of the existing CSI instrument used by Mokhlis (2009) has never been re-evaluated by any study; hence the need to ascertain Malaysian CSI components arises. It is believed that the profile of Malaysian college students may also have certain distinctive 
characteristics to their decision-making styles which could be of great interest to researchers, consumer educationists and marketers.

Sproles and Kendall (1986) CSI instrument is widely seen as a theoretical background to most CSI instruments. As a result, many researchers have modified the original eight (8) components of CSI scales from Sproles and Kendall (1986) to suit their respective studies and locations. It is hopeful that the present study's modification of the original 40 CSI scale developed by Sproles and Kendall (1986) will deepen the understanding of college students' shopping decision making styles in Malaysian context, provide a more definitive conclusion about the role of students' background and family background.

For better understanding of Malaysian college students' decision-making styles, the study has the following objectives: (i) to identify CSI components in Malaysian context. (ii) To determine the role of students' background and family on CSI components.

\section{Literature Review}

\subsection{Consumer Decision Making Styles}

The investigation of consumer decision-making has a long tradition in marketing and consumer behavior research. Considerable scientific effort has been given in recent times towards exploration of consumers' decision-making styles (Bauer, Sauer, and Becker 2006). Three approaches have been suggested in consumer behavior literature to characterize consumer styles. They are psychographic/lifestyle approach, the consumer typology approach, and the consumer characteristics approach (Sproles and Kendall 1986). Subsequent to consumer characteristics approach, Sproles and Kendall (1986) combined these decision-making traits and additional traits to develop a consumer decision-making styles inventory (CSI), a comprehensive instrument that measures eight mental characteristics of consumer decision-making. The CSI was developed and validated from a sample of 482 American high school students who were asked about their decision-making styles for personal products like clothing, cosmetics and hairdryers (Bakewell and Mitchell 2004). Forty items pertaining to affective and cognitive orientations in decision making are grouped into eight potential styles or traits affecting behavior. The eight mental characteristics of consumer decision making styles in CSI as listed by Sproles and Kendall (1986) are as follows:

Brand Conscious, "price equals quality" consumer: Consumers in this category believe the higher the price of the product, the higher also is the quality. They prefer popular and highly advertised brands. Such consumers usually shop in highly reputable shops which are synonymous with big brands and high prices. This class of consumers believes in Veblen products.

Perfectionist, high quality conscious consumer: Perfectionist consumers consider the best in class (quality products). Such types of consumers are very careful in their shopping and critically evaluate the pros and cons of a product before deciding to buy a particular product. Purchasing at exorbitant prices is not their problem, but their yardstick is always high quality.

Recreational and hedonistic shopping consciousness consumers: Consumers in this category find shopping pleasant and just shop for the fun of it. They are mostly extravagant in their shopping and never consider the actual importance of the particular product they are buying.

Habitual, brand loyal consumers: This is a composition of consumers with favorite brands and stores in a shopping setting. Such consumers form the habits of choosing a particular brand or buying from the same store all the time. They are brand/store loyalists irrespective of market prices. Also, they are hardly influenced by market forces.

Novelty-fashion conscious consumers: This class of consumers is excited and carried away with new things. They thrive to keep up-to-date with latest fashion trends. They also exhibit ostentatious behavior through shopping which in turn help them to maintain their societal class.

Impulsive, careless consumer: Consumers in this category do not plan their shopping and are nonchalant over how they spend their resources in shopping. They can regret their purchasing decisions after a while. A common attribute of this class of consumers is non-budget style purchase.

Confused by over choice consumer: Consumers in this class are in difficult situations while making purchase decisions. They perceive many brands and stores which lead them to mix-up on which brand or store to buy. Such consumers experience excessive information and thus deviate from their original purchasing plans. This is a resultant force of numerous stores or brands available in the market.

Price conscious, "value for money" consumers: Consumers in this class look for sales prices, concerned in 
getting the best value for their money and also compare the products. Such consumers appear conscious of lower prices in general. They also tend to purchase more items at sales price.

Research has shown that consumers often display consistent decision-making styles to channel their decision-making during purchases (Durvasula, Lysonski and Andrews, 1993; Evans, Christiansen and Gill, 1996). However, their decision-making styles are most times altered by individual background and family background. These two factors play a prominent role in defining the decision making style of modern consumers. For instance, the purchasing style or habit of an individual from a wealthy family is different from that of an individual from a poor background. Likewise the difference between purchasing styles of consumers that grew up in the rural areas and urban areas. In Malaysian context, college students' decision making styles are dependent on different things such as, friends, tastes and preferences, sex, student's background, family background, ethnicity and place where the student was raised (location). All these factors are anchored on the family background of a college student.

\subsection{Effects of Demographic Variables on CDMS}

Previous studies showed demographics affect CDMS (Kamaruddin and Kamarudin, 2009). For instance, younger college students are more likely to be hedonistic, habitual and novelty consciousness than older college students. However, older college students are more interested in historical, quality products and being affordable at the same time. Younger college students are likely to be more confused and impulsive than older college students; hence, Wickliffe (2004) opined that consumers under the age of 30 are categorized as more confused and impulsive than consumers over 30 years old. Some early studies which examined the impacts of gender on buying behavior/decision making styles found differences between male and female (Bakewell and Mitchell, 2003). Extant studies suggest that females tend to choose well-known brands significantly more often than males. They are also more willing to pay higher prices for brands, and exhibit stronger brand involvement (Mitchell and Walsh, 2004; Mukherjee et al., 2012), while some studies asserted that this relationship is not so clear (Kumar and Sarangi, 2008; Anic et al., 2010).

Also, Bakewell and Mitchell (2006) found that different ethnic groups have different impact on CDMS and consumer behavior. For instance, Malays, Chinese and Indians which are the three major ethnic groups in Malaysia have different behaviours as Malaysian consumers. But in some factors, they are similar. For instance, in the case of price and quality (in service industry) the Malays and Chinese are the same (Ariffin et al., 2008). Investigations also showed that Malay consumers are more patriotic and brand conscious to local products and more ethnocentric compared to Chinese and Indians (Othman, Ong and Wong, 2008).

Also, consumers' location has significant impact on their style inventory (Madahi et al., 2012). Consumer decision making styles vary according to cultural orientation Leo, Bennett and Hartel (2005), which is affected by location. For instance, college students in urban areas have different shopping decision making styles from those in rural areas. The reason is that college students from urban areas are more exposed to the latest fashion in vogue and have more access to internet unlike their counterparts in the rural areas. According to Madahi et al. (2012), rural consumers are more affected by social norms, social conventions and are more traditional. College students from big family sizes and high income tend to be quality conscious, novelty, brand and fashion more than their counterparts from small family size and low income homes. On the other hand, college students from small size families and low income homes are prone to price value conscious. They also tend to be confused by over choice and impulsive during promotional sales (offer).

\section{Methodology}

\subsection{The Data}

The data were collected among college students enrolled at five public and private higher learning institutions in Klang Valley, Malaysia. A total of 460 on-campus and off-campus students from each university participated in the study. For on-campus students, stratified sampling method was employed in selection of respondents. However, somewhat different method was utilized to collect data from off-campus respondents. Given the fact that smaller numbers of students live off-campus, 60 sets of questionnaires were randomly distributed to off-campus respondents in the five institutions of higher learning. After data collection, 2,068 questionnaires were found useable for the study, amounting to approximately $90 \%$ valid responses. The three major ethnic groups in Malaysia (Malay, Chinese and Indians) were incorporated in the study.

The research instrument was a set of questionnaires and administered by trained enumerators. It consisted of 25 Likert scaled-items adopted from Sproles and Kendall's (1986) consumer style inventory (CSI). Each item was answered by a 4-point Likert scale; ranging from 1 (strongly disagree) to 4 (strongly agree). The reliabilities of the original CSI scale from Sproles and Kendall (1986) ranged from .48 to .76. However, the present study's CSI 
scale reliability improved from Sproles and Kendall (1986) and previous Malaysian CDMS studies, ranging from .48 to .84 . The items were randomly ordered in a self-administered CSI instrument to counterbalance possible order effects. In addition, some demographic questions were included in the questionnaire.

\subsection{Variable Definition and Data Analysis}

Exploratory factor analysis (EFA) was utilized at the initial stage to determine the number of factors that the 25 items adopted from Sproles and Kendall (1986) CSI will yield in Malaysian context. EFA was also used to ascertain the construct validity of the instrument. The dependent variable is individual components of CSI extracted via EFA namely, "Brand conscious", "Perfectionist", "Recreational and hedonistic", "Habitual", "novelty-fashion conscious", "confused by over-choice", and "price value conscious". As such, there are seven hierarchical regression models developed for the purpose. The independent variables are grouped as follows: (1) students' background consisted of gender, age, ethnicity and place where the student was raised. (2) Family background comprised of family size and household income.

Hierarchical regression was used to assess the ability of two control measures (college students' background and family background) in predicting each of the seven dependent variables (CSI components extracted through EFA). Preliminary analyses indicated that the assumptions of normality, linearity, multicollinearity and homoscedasticity for the model are not violated.

The generic hierarchical model is as follows:

$$
Y=a+b_{1}+X_{1}+b_{2}+X_{2}
$$

Where

$\mathrm{Y}=$ Individual CSI components

$\mathrm{a}=\mathrm{Y}$-intercept

$\mathrm{b}=$ Slope of the line

$\mathrm{X}_{1}=$ Students' background

$\mathrm{X}_{2}=$ Family background

\section{Results and Discussions}

\subsection{Sample Characteristics}

About $62.8 \%$ of the respondents $(2,068)$ are females, $84.5 \%$ were less than 22 years old. Majority of the respondents (84.2\%) are Malays, followed by Chinese $(9.1 \%)$ and Indians (3.7\%). Almost all the respondents were single (99.1\%). About $37.5 \%$ of the respondents are from small sized families ( $\leq 5$ people) and more than $54.2 \%$ were from families that consisted of at least six members. Respondents whose family income is less than MYR1500 per month constituted 34.2\%. Those from families earning between MYR1600 and MYR5000 per month were $43.4 \%$, while about $17 \%$ came from families with income between MYR5100 and MYR10000 per month. Malaysian currency is Ringgit Malaysia (RM) or internationally abbreviated as MYR. About $36.5 \%$ of the respondents were raised in the rural areas, $21.7 \%$ were raised in small town, and $40 \%$ were raised in (big) town, while $1.8 \%$ was raised in metropolitan areas.

\subsection{Identification of CSI Components among Malaysian College Students}

Exploratory Factor Analysis (EFA) was conducted on 25 items of Consumer Style inventory (CSI) adopted from Sproles and Kendall (1986). The Kaiser-Meyer-Olkim (KMO) was .869, exceeded the recommended value of .6 (Kaiser, 1974) and Bartlett's Test of Sphericity was highly significant $(\mathrm{p}<.001)$, supporting the sample adequacy and factorability of the correlation matrix. The principle component analysis extracted seven components with eigenvalues that exceeded 1 and explained $65.4 \%$ of model variance. A rotated factor analysis was performed using Varimax rotation to give a clearer separation as suggested by Hair et al. (1998). Results of the rotated factor analysis revealed an interpretable seven-factor solution as shown in Table 1. All the 25 items have factor loadings greater than 0.4 and there were no cross-loadings. This resulted in retaining the 25 items. According to the structure of the factor loading of the items, the factors were named in line with Sproles and Kendall (1986) as they reflect similar decision making characteristics. Five out of the 7-items that measured brand consciousness belongs to the same decision making style factor in Sproles and Kendall (1986) study. Four out of the 5-items that measured perfectionist consciousness are consistent with Sproles and Kendall (1986), Hafstrom et al. (1992), and $\mathrm{Ng}$ (2005), while 2-items in the present study are in tandem with hedonistic and recreational consciousness in their studies.

The present study's habitual and brand loyal characteristics has exactly the same 3-items used in Sproles and 
Kendall (1986), and $\mathrm{Ng}$ (2005), while novelty-fashion consciousness has only 1-item that corresponds with Sproles and Kendall (1986), and Hafstrom et al. (1992) studies. The 2-items that measured confused by over choice consciousness in the present study are consistent with the studies of Sproles and Kendall (1986), Hafstrom et al. (1992), and $\mathrm{Ng}$ (2005), while the 2-items that measured price-value consciousness are in tandem with the studies of Sproles and Kendall (1986), Hafstrom et al. (1992), and Ng (2005). Due to cultural and psychological differences, some of the items that measured the above seven dimensions of CDMS were factored into impulsive consciousness which the results of EFA in the present study did not reveal as a separate factor.

Table 1. Decision-Making style factors

\begin{tabular}{|c|c|c|c|}
\hline Factors/Components & Factor loading & Eigen values & Variance explained \\
\hline Brand \& Fashion Conscious & & 6.641 & 26.563 \\
\hline $\begin{array}{l}\text { The well-known brands are best } \\
\text { for me }\end{array}$ & .754 & & \\
\hline The more expensive brands are usually my choice & .797 & & \\
\hline $\begin{array}{l}\text { Nice department and specialty } \\
\text { stores offer me the best products }\end{array}$ & .513 & & \\
\hline $\begin{array}{l}\text { I usually have one more outfits } \\
\text { of the very newest style }\end{array}$ & .714 & & \\
\hline $\begin{array}{l}\text { I keep my wardrobe up to date } \\
\text { with the changing fashions }\end{array}$ & .710 & & \\
\hline $\begin{array}{l}\text { Fashionable, attractive styling is } \\
\text { very important to me }\end{array}$ & .609 & & \\
\hline $\begin{array}{l}\text { Often I make careless purchases; } \\
\text { I later wish I had not }\end{array}$ & .427 & & \\
\hline Perfectionist Conscious & & 3.019 & 12.075 \\
\hline $\begin{array}{l}\text { Getting very good quality products } \\
\text { is very important to me }\end{array}$ & .829 & & \\
\hline $\begin{array}{l}\text { When it comes to purchasing } \\
\text { products, I try to get the very } \\
\text { best or perfect choice }\end{array}$ & .848 & & \\
\hline In general, I usually try to buy the best overall quality & .784 & & \\
\hline $\begin{array}{l}\text { I make special effort to choose } \\
\text { the very best quality products }\end{array}$ & .785 & & \\
\hline $\begin{array}{l}\text { I look carefully to find the best } \\
\text { value }\end{array}$ & .554 & & \\
\hline Hedonistic \& Recreational Conscious & & 1.741 & 6.963 \\
\hline $\begin{array}{l}\text { Shopping is a pleasant activity for } \\
\text { me }\end{array}$ & .810 & & \\
\hline $\begin{array}{l}\text { Going shopping is one of the } \\
\text { enjoyable activities of my life }\end{array}$ & .834 & & \\
\hline $\begin{array}{l}\text { I enjoy shopping just for the fun } \\
\text { of it }\end{array}$ & .679 & & \\
\hline $\begin{array}{l}\text { Habitual \& Brand-loyal } \\
\text { Conscious }\end{array}$ & & 1.485 & 5.939 \\
\hline $\begin{array}{l}\text { I have favorite brands I buy over } \\
\text { and over }\end{array}$ & .726 & & \\
\hline $\begin{array}{l}\text { Once I find a product or brand I } \\
\text { like, I stick to it }\end{array}$ & .801 & & \\
\hline I go to the same store each time I shop & .663 & & \\
\hline Novelty Conscious & & 1.289 & 5.155 \\
\hline $\begin{array}{l}\text { I take the time to shop carefully } \\
\text { for best buys }\end{array}$ & .461 & & \\
\hline $\begin{array}{l}\text { Often times, I feel confused } \\
\text { because there are so many } \\
\text { brands to choose from }\end{array}$ & .811 & & \\
\hline
\end{tabular}




\begin{tabular}{|c|c|c|c|}
\hline $\begin{array}{l}\text { Sometimes it is hard to choose } \\
\text { which stores to shop }\end{array}$ & .795 & & \\
\hline Confused by over choice & & 1.106 & 4.424 \\
\hline $\begin{array}{l}\text { The more I learn about products, the harder it seems to choose the } \\
\text { best }\end{array}$ & .837 & & \\
\hline All the information I get on different products confuse me & .838 & & \\
\hline Price-value Conscious & & 1.065 & 4.260 \\
\hline I buy as much as possible at sale prices & .559 & & \\
\hline $\begin{array}{l}\text { The lower price products are } \\
\text { usually my choice }\end{array}$ & .834 & & \\
\hline Total Variance Explained & & 65.379 & \\
\hline
\end{tabular}

\subsection{Reliability of CDMS Scales/Factors}

Table 2 summarized findings of the reliability analysis which assessed the internal consistencies of the total scores of each subscale. Apart from "price-value", six of the seven factors recorded high Cronbach alpha ranging from .638 to .843 . Although price-value factor gave a low reliability (alpha coefficient $=.477$ ), it was still adopted for the purpose of the study due to the following reasons: First, it was determined through EFA that the factor could be used to test CDMS. Given the number of items used to measure price-value factor, the low alpha value is acceptable since both items loaded above the cut-off point used in determining the factors and items to retain. As such, with factor loadings above .4, it is regarded as valid and if a factor is measured with less than three items, an alpha value of .477 and above becomes acceptable and reliable. This makes price-value inclusive in the number of CDMS characteristics of Malaysian college students. Second, the low reliability coefficient for price-value factor is consistent with Mokhlis and Salleh (2009), implying that Malaysian college students sensitize price-value factor much in their decision making styles. Despite having a slightly higher reliability alpha for this factor, Bakewell and Mitchell (2006); and Hanzaee and Aghasibeig (2008) recorded lower reliabilities on price value and low price seeking factor of CDMS respectively. This further indicates that consumers are generally conscious of product prices and values even beyond the borders of Malaysia.

Table 2. Reliability analysis for the scales

\begin{tabular}{lll}
\hline Factors & No. of Items & Cronbach Alpha \\
\hline Brand \& Fashion & 7 & .84 \\
Perfectionist & 5 & .84 \\
Hedonistic \& Recreational & 3 & .83 \\
Habitual \& Brand Loyalty & 3 & .70 \\
Novelty-fashion & 3 & .64 \\
Confused by over choice & 2 & .77 \\
Price-value & 2 & .48 \\
\hline
\end{tabular}

\subsection{Determination of Two Control Measures on Seven Factors/Subscales of CDMS}

\section{i. CDMS: Brand fashion factor/subscale}

Result indicated that student's background explained $2.5 \%$ of the variance on brand fashion factor. After the entry of student's family background at step two, the total variance explained by the model as a whole was $3.6 \%$, $\mathrm{F}(6,2061)=12.878, \mathrm{p}<.001$. As illustrated in table 3 , the two control measures explained additional $1.1 \%$ of the variance on brand fashion factor after controlling for student's background, $\mathrm{R}$ squared change $=.011, \mathrm{~F}$ change $(2,2061)=11.622, p<.001$. Four out of the six variables that constituted the two control measures made statistically significant contribution in the final model, with gender recording a higher beta value $(\beta=-5.82, p$ $<.001)$ than family size $(\beta=-3.64, \mathrm{p}<.001)$; followed by household income $(\beta=2.87, \mathrm{p}<.01)$ and age $(\beta=$ $2.06, \mathrm{p}<.05)$

The result implies that Malaysian college students' gender play the most prominent role in brand fashion factor of their shopping decision making styles, with family size, household income, and age contributing to brand fashion factor of their decision making styles. The study submits that the above four significant contributors determine Malaysian college students' decision on brand fashion factor. 
Table 3. Role of demographic characteristics on brand fashion factor of CSI $(\mathrm{n}=2068)$

\begin{tabular}{|c|c|c|c|c|c|c|c|c|}
\hline \multicolumn{5}{|l|}{ Model 1} & \multicolumn{4}{|c|}{ Model 2} \\
\hline Variables & B & SE & B & t & B & SE & $\beta$ & t \\
\hline Constant & 16.353 & 1.293 & - & $12.650 * * *$ & 17.742 & 1.341 & - & $13.234 * * *$ \\
\hline Gender & -1.188 & .197 & -.132 & $-6.031 * * *$ & -1.143 & .196 & -.127 & $-5.820 * * *$ \\
\hline Age & .131 & .056 & .051 & $2.345^{*}$ & .114 & .055 & .045 & $2.062^{*}$ \\
\hline Ethnicity & -.202 & .143 & -.031 & -1.412 & -.225 & .143 & -.034 & -1.575 \\
\hline Place where the student was raised & .481 & .192 & .055 & $2.500^{*}$ & .318 & .194 & .036 & 1.633 \\
\hline Family size & & & & & -.155 & .043 & -.080 & $-3.639 * * *$ \\
\hline Household income & & & & & .000 & .000 & .063 & $2.871 * *$ \\
\hline $\mathbf{R}^{2}$ & & & .025 & & & & .036 & \\
\hline $\mathbf{F}$ & & & $12.878 * * *$ & & & & $11.622 * * *$ & \\
\hline$\Delta \mathbf{R}^{2}$ & & & & & & & .011 & \\
\hline
\end{tabular}

Note: $\mathrm{B}=$ unstandardized beta; $\beta=$ standardized beta; $\mathrm{F}=\mathrm{f}$ statistics; $\mathrm{t}=\mathrm{t}$ statistics; $\mathrm{R}^{2}=$ variance;

$\Delta \mathrm{R}^{2}=$ change in variance; $*=(\mathrm{p})<.05 ; * *=(\mathrm{p})<.01 ; * * *=(\mathrm{p})<.001$

\section{ii. CDMS: Perfectionist factor/subscale}

For the perfectionist factor model, student's background explained .8\% of the variance on perfectionist factor. Upon entry of student's family background at the second step, the overall variance explained by the model was $1.6 \%, \mathrm{~F}(6,2061)=5.440, \mathrm{p}<.001$. As depicted in table 4 , the two control measures explained additional variance of $.8 \%$ in perfectionist factor, $R$ squared change $=.008, \mathrm{~F}$ change $(2,2061)=7.831, \mathrm{p}<.001$. Four out of the six variables that made up the two control measures had statistically significant contribution in the final model, with family size recording a higher beta value $(\beta=-3.35, \mathrm{p}<.01)$ than gender $(\beta=2.58, \mathrm{p}<.05)$; place where the student was raised $(\beta=-2.52, \mathrm{p}<.05)$ and age $(\beta=.2 .21, \mathrm{p}<.05)$.

The finding indicates that family size, gender, place where the student was raised and age are the determinants of college students' perfectionist factor in shopping decision making styles. In addition, it shows that Malaysian college students from small family sizes will likely have an opposite preference relative to those from larger family size. It also depicts that male and female college students have different tastes and preferences in perfectionist factor of decision making styles. Despite having a small continuum of age difference among Malaysian college students, age also determines the perfectionistic nature of Malaysian college students, hence the older a college student is, the higher the perfectionistic taste the student has.

Table 4. Role of demographic characteristics on perfectionist factor of CSI $(n=2068)$

\begin{tabular}{|c|c|c|c|c|c|c|c|c|}
\hline \multirow{2}{*}{$\begin{array}{l}\text { Model } 1 \\
\text { Variables } \\
\end{array}$} & \multirow[b]{2}{*}{ B } & \multicolumn{7}{|c|}{ Model 2} \\
\hline & & SE & B & $\mathbf{t}$ & B & SE & $\beta$ & $\mathbf{t}$ \\
\hline Constant & 14.655 & .844 & - & $17.374 * * *$ & 15.488 & .876 & - & $17.673 * * *$ \\
\hline Gender & .305 & .129 & .052 & $2.369^{*}$ & .331 & .128 & .057 & $2.578^{*}$ \\
\hline Age & .089 & .036 & .054 & $2.451^{*}$ & .080 & .036 & .049 & $2.207 *$ \\
\hline Ethnicity & -.141 & .093 & -.033 & -1.515 & -.160 & .094 & -.038 & -1.708 \\
\hline Place where the student was raised & -.233 & .126 & -.041 & -1.857 & -.320 & .127 & -.056 & $-2.518^{*}$ \\
\hline Family size & & & & & -.093 & .028 & -.075 & $-3.349 * *$ \\
\hline Household income & & & & & .000 & .000 & .041 & 1.844 \\
\hline $\mathbf{R}^{2}$ & & & .008 & & & & .016 & \\
\hline $\mathbf{F}$ & & & $5.440 * * *$ & & & & $7.831 * * *$ & \\
\hline$\Delta \mathbf{R}^{2}$ & & & & & & & .008 & \\
\hline
\end{tabular}

Note: $\mathrm{B}=$ unstandardized beta $\beta=$ standardized beta $F=f$ statistics $; \mathrm{t}=\mathrm{t}$ statistics $; \mathrm{R}^{2}=$ variance;

$\Delta \mathrm{R}^{2}=$ change in variance $*=(\mathrm{p})<.05 ; * *=(\mathrm{p})<.01 ; * * *=(\mathrm{p})<.001$.

\section{iii. CDMS: Hedonistic/recreational factor/subscale}

For hedonistic/recreational factor, student's background explained $1.1 \%$ of the variance in 
hedonistic/recreational factor. Upon entry of student's family background the model explained $1.2 \%$ variance on hedonistic/recreational factor as a whole, $\mathrm{F}(6,2061)=4.214, \mathrm{p}<.001$. As depicted in table 5 , the two control measures explained an additional variance of .1\% in hedonistic/recreational factor, $\mathrm{R}$ squared change $=.001, \mathrm{~F}$ change $(2,2061)=1.523$. Three out of the six variables that made up the two control measures made statistically significant contribution in the final model, with gender recording a higher beta value $(\beta=3.44, p<.01)$ than ethnicity $(\beta=-2.65, \mathrm{p}<.01)$ and age $(\beta=2.19, \mathrm{p}<.05)$.

The inferences imply that gender influences Malaysian college students' hedonistic/recreational factor most. This is followed by ethnicity and age. It further shows that gender, ethnicity and age drive Malaysian students' passion for hedonistic/recreational factor while making shopping decisions. This is evident in the way male college students prioritise certain things relative to female college students. Ethnicity serves as a defining variable to hedonistic factor, indicating that based on a college student's ethnicity, he/she may be hedonistic in nature during shopping decision making. Age on its own gives credence to hedonistic/recreational factor as younger college students tend to make certain shopping decisions for the sake of fun or pleasure.

Table 5. Role of demographic characteristics on hedonistic factor of CSI $(n=2068)$

\begin{tabular}{|c|c|c|c|c|c|c|c|c|}
\hline Model 1 & & & & & Model 2 & & & \\
\hline Variables & B & SE & B & $\mathrm{t}$ & B & SE & $\beta$ & $\mathrm{T}$ \\
\hline Constant & 6.232 & .668 & - & $9.328 * * *$ & 6.410 & .696 & - & $9.205 * * *$ \\
\hline Gender & .344 & .102 & .074 & $3.375 * *$ & .350 & .102 & .076 & $3.436 * *$ \\
\hline Age & .066 & .029 & .050 & $2.279 *$ & .063 & .029 & .048 & $2.186^{*}$ \\
\hline Ethnicity & -.197 & .074 & -.059 & $-2.669 * *$ & -.197 & .074 & -.059 & $-2.650 * *$ \\
\hline $\begin{array}{l}\text { Place where the } \\
\text { student was } \\
\text { raised }\end{array}$ & .111 & .099 & .025 & 1.119 & .082 & .101 & .018 & .814 \\
\hline Family size & & & & & -.020 & .022 & -.020 & -.888 \\
\hline $\begin{array}{l}\text { Household } \\
\text { income }\end{array}$ & & & & & .000 & .000 & .032 & 1.430 \\
\hline $\mathrm{R}^{2}$ & & & .011 & & & & .012 & \\
\hline $\mathrm{F}$ & & & $4.214 * * *$ & & & & 1.523 & \\
\hline$\Delta \mathrm{R}^{2}$ & & & & & & & .001 & \\
\hline
\end{tabular}

Note: $\mathrm{B}=$ unstandardized beta; $\beta=$ standardized beta $\mathrm{F}=\mathrm{f}$ statistics; $\mathrm{t}=\mathrm{t}$ statistics $; \mathrm{R}^{2}=$ variance;

$\Delta \mathrm{R}^{2}=$ change in variance $*=(\mathrm{p})<.05 ; * *=(\mathrm{p})<.01 ; * * *=(\mathrm{p})<.001$.

\section{iv. CDMS: Habitual factor/subscale}

Student's background explained $1.3 \%$ variance on habitual/brand loyal factor and student's family background explained $2.1 \%$ variance on habitual factor, $\mathrm{F}(6,2061)=7.394, \mathrm{p}<.001$. As illustrated in table 6 , the two control measures explained additional variance of $.8 \%$ on habitual/brand loyal factor after controlling for student's background, R squared change $=.008$, F change $(2,2061)=8.756, \mathrm{p}<.001$. Four out of the six variables that constituted the two control measures made statistically significant contribution in the final model, with ethnicity recording a higher beta value $(\beta=-4.19, \mathrm{p}<.001)$ than family size $(\beta=-2.87, \mathrm{p}<.01)$, followed by household income $(\beta=2.82, \mathrm{p}<.01)$ and age $(\beta=2.70, \mathrm{p}<.01)$.

The result implies that ethnicity, family size, household income and age determine the choices of Malaysian college students on habitual/brand loyal factor of decision making style. This means that college students' loyalty to particular brands or items while making shopping decisions is influenced by their ethnicity. This is undoubtedly because of racial influence, as most college students like following their ethnic buying style and favourite brand. Also, students' family size and household income as significant contributors of this factor drives the student's morale in placing a special attachment to certain brands. Hence, with reasonable household income, college students can maintain their habitual brands, while their family size raises their ego in maintaining the brand. On the other hand, age range of college students is linked to their shopping habits, meaning that certain age group among college students are fond of particular brands or stores. 
Table 6. Role of demographic characteristics on habitual factor of CSI $(n=2068)$

\begin{tabular}{|c|c|c|c|c|c|c|c|c|}
\hline & Model 1 & & & & Model & & & \\
\hline Variables & B & SE & $\boldsymbol{\beta}$ & $\mathbf{t}$ & B & SE & $\boldsymbol{\beta}$ & $\mathbf{T}$ \\
\hline Constant & 6.623 & .604 & - & $10.960 * * *$ & 7.137 & .628 & - & $11.372 * * *$ \\
\hline Gender & .111 & .092 & .027 & 1.205 & .128 & .092 & .031 & 1.398 \\
\hline Age & .076 & .026 & .065 & $2.938^{* *}$ & .070 & .026 & .059 & $2.699 * *$ \\
\hline Ethnicity & -.274 & .067 & -.090 & $-4.106^{* * *}$ & -.281 & .067 & -.093 & $-4.194 * * *$ \\
\hline Place where the student was raised & .081 & .090 & .020 & .903 & .015 & .091 & .004 & .167 \\
\hline Family size & & & & & -.057 & .020 & -.064 & $-2.869 * *$ \\
\hline Household income & & & & & .000 & .000 & .062 & $2.816^{* *}$ \\
\hline $\mathbf{R}^{2}$ & & & .013 & & & & .021 & \\
\hline $\mathbf{F}$ & & & $7.394 * * *$ & & & & $8.756 * * *$ & \\
\hline$\Delta \mathbf{R}^{2}$ & & & & & & & .008 & \\
\hline
\end{tabular}

Note: $\mathrm{B}=$ unstandardized beta; $\beta=$ standardized beta; $\mathrm{F}=\mathrm{f}$ statistics; $\mathrm{t}=\mathrm{t}$ statistics; $\mathrm{R}^{2}=$ variance;

$\Delta \mathrm{R}^{2}=$ change in variance; $*=(\mathrm{p})<.05 ; * *=(\mathrm{p})<.01 ; * * *=(\mathrm{p})<.001$

\section{v. CDMS: Novelty factor/subscale}

Table 7 summarized the role of two control measures on novelty factor of CSI. Student's background explained $3.9 \%$ of the variance on novelty fashion. At step two, student's family background explained $4.2 \%$ of the model variance $\mathrm{F}(6,2061)=15.119, \mathrm{p}<.001$. The two control measures explained additional $.3 \%$ of the variance in novelty after controlling for student's background, $\mathrm{R}$ squared change $=.003$, F change $(2,2061)=3.932, \mathrm{p}<.05$. In the final model, three variables out of the six that formed the two control measures made statistically significant contribution, with gender recording a higher beta value $(\beta=-5.87, \mathrm{p}<.001)$ than age $(\beta=4.95, \mathrm{p}$ $<.001)$ and ethnicity $(\beta=-3.14, \mathrm{p}<.01)$.

Results from the analysis depict gender, age and ethnicity as the galvanizers of Malaysian college students' decision towards novelty factor. This implies that college students' gender, age and ethnicity cause them to make different and unusual shopping decisions. The shopping decision making styles of female college students tend to vary from time to time unlike male students. In the same way, younger college students are more novelty conscious than older college students as the latter have low tendencies of novelty conscious. Older college students are mostly not interested in trying new and unusual items during shopping decision. They prefer familiar and usual items thereby avoiding the risk in trying new products. College students' ethnicity drives their enterprising behaviors. For instance, Chinese students are fond of trying new products unlike the Malay and Indian college students. The Malays and Indians believe that trying different or new items may lead to shopping mistakes and loss of resources.

Table 7. Role of demographic characteristics on novelty factor of CSI $(n=2068)$

\begin{tabular}{|c|c|c|c|c|c|c|c|c|}
\hline \multirow[b]{2}{*}{ Variables } & \multicolumn{4}{|c|}{ Model 1} & \multicolumn{4}{|c|}{ Model 2} \\
\hline & B & SE & $\beta$ & $\mathbf{t}$ & B & SE & $\beta$ & $\mathbf{t}$ \\
\hline Constant & 7.016 & .577 & - & $12.161 * * *$ & 7.346 & 601 & - & $12.232 * * *$ \\
\hline Gender & -.527 & .088 & -.130 & $-5.995 * * *$ & -.516 & .088 & -.128 & $-5.867 * * *$ \\
\hline Age & .127 & .025 & .111 & $5.117 * * *$ & .123 & .025 & .108 & $4.951 * * *$ \\
\hline Ethnicity & -.197 & .064 & -.067 & $-3.088 * *$ & -.201 & .064 & -.069 & $-3.139 * *$ \\
\hline Place where the student was raised & .042 & .086 & .011 & .495 & .000 & .087 & .000 & .001 \\
\hline Family size & & & & & -.037 & .019 & -.042 & -1.927 \\
\hline Household income & & & & & .000 & .000 & .041 & 1.882 \\
\hline $\mathbf{R}^{2}$ & & & .039 & & & & .042 & \\
\hline $\mathbf{F}$ & & & $15.119 * *$ & & & & $3.932 *$ & \\
\hline$\Delta \mathbf{R}^{2}$ & & & & & & & .003 & \\
\hline
\end{tabular}

Note: $\mathrm{B}=$ unstandardized beta; $\beta=$ standardized beta; $F=f$ statistics; $t=t$ statistics; $R^{2}=$ variance;

$\Delta \mathrm{R}^{2}=$ change in variance; $*=(\mathrm{p})<.05 ; * *=(\mathrm{p})<.01 ; * * *=(\mathrm{p})<.001$. 


\section{vi. CDMS: Confused by Over-choice factors/subscale}

Table 8 summarized the role of two control measures on confused by over choice factor of CSI. Students' background explained .7\% of the variance on confused by over choice. Upon entry of student's family background at the second step, the overall variance explained by the model was $1 \%, F(6,2061)=3.603, p<.01$. The two control measures explained additional .3\% of the variance in confused by over choice after controlling for student's background, R squared change $=.003, \mathrm{~F}$ change $(2,2061)=3.041, \mathrm{p}<.05$. In the final model, three out of the six variables that formed the two control measures had statistically significant contribution, with ethnicity recording a higher beta value $(\beta=-2.96, \mathrm{p}<.01)$ than place where the student was raised $(\beta=-2.27, \mathrm{p}$ $<.05)$ and family size $(\beta=-1.98, \mathrm{p}<.05)$.

The result indicates that the tendency of a college student to be confused by over choice relies on the student's ethnicity, place where the student was raised and family size. Malay college students place special attachment to their ethnicity with due observation to their norms unlike the Chinese and Indian students. This singles out Malay college students as people that love to make shopping decisions that correspond with their ethnic norms (buying indigenous products). While trying to make shopping decisions that will conform to their ethnicity, they sometimes get confused by over choice due to high number of affordable new brands. The location a college student was raised is a defining factor of his/her confusion level while making shopping decision. Rural areas are known for not having most of the fashion/brand in vogue, thus, a student raised in such places tend to be confused when exposed to a market with several options. Family size on the other hand shapes college students' likelihood of being confused by over choice. Students from big sized families tend to be confused by over choice more than their counterparts from small families. College students always consider their family size, and students from big families are more patriotic to indigenous items due to its affordability. With several items at low prices, students from big family size easily get confused by over choice.

Table 8 . Role of demographic characteristics on confused by over choice factor $(n=2068)$

\begin{tabular}{|c|c|c|c|c|c|c|c|c|}
\hline \multirow[b]{2}{*}{ Variables } & \multicolumn{4}{|c|}{ Model 1} & \multicolumn{4}{|c|}{ Model 2} \\
\hline & B & SE & $\boldsymbol{\beta}$ & $\mathbf{t}$ & B & SE & B & $\mathbf{t}$ \\
\hline Constant & 6.477 & .462 & - & $14.007 * * *$ & 6.748 & .482 & - & $14.013 * * *$ \\
\hline Gender & -.079 & .070 & -.025 & -1.122 & -.070 & .071 & -.022 & -.998 \\
\hline Age & -.026 & .020 & -.029 & -1.304 & -.029 & .020 & -.032 & -1.454 \\
\hline Ethnicity & -.147 & .051 & -.063 & $-2.872 * *$ & -.152 & .051 & -.066 & $-2.961 * *$ \\
\hline Place where the student was raised & -.129 & .069 & -.041 & -1.872 & -.159 & .070 & -.051 & $-2.274^{*}$ \\
\hline Family size & & & & & -.030 & .015 & -.044 & $-1.979 *$ \\
\hline Household income & & & & & .000 & .000 & .029 & 1.314 \\
\hline $\mathbf{R}^{2}$ & & & .007 & & & & .010 & \\
\hline $\mathbf{F}$ & & & $3.603 * *$ & & & & $3.041 *$ & \\
\hline$\Delta \mathbf{R}^{2}$ & & & & & & & .003 & \\
\hline
\end{tabular}

Note: $\mathrm{B}=$ unstandardized beta; $\beta=$ standardized beta; $\mathrm{F}=\mathrm{f}$ statistics; $\mathrm{t}=\mathrm{t}$ statistics $; \mathrm{R}^{2}=$ variance;

$\Delta \mathrm{R}^{2}=$ change in variance $* *=(\mathrm{p})<.05 ; * *=(\mathrm{p})<.01 ; * * *=(\mathrm{p})<.001$

\section{vii. CDMS: Price value factor/subscale}

In Price value factor model, Students' background explained $1.3 \%$ of the variance. Student's family background at the second step, explained $1.4 \%$, of the overall variance $F(6,2061)=5.029, p<.001$. As depicted in table 9 , the two control measures explained only .1\% additional variance in price value factor, $\mathrm{R}$ squared change $=.001$, F change $(2,2061)=1.560$. Only two out of the six variables that constituted the two control measures made statistically significant contribution in the final model, with gender recording a higher beta value $(\beta=-3.86, p$ $<.001)$ than age $(\beta=2.72, \mathrm{p}<.001)$.

The result is an indication that gender and age of Malaysian college students drive their price value consciousness in shopping decision making. Male college students are more likely to sensitize price value during shopping decisions. Unlike male students, females do not prioritize prices while making decision towards items they like. However, both male and female college students tend to buy more items during sales promotion (offer). Older college students consider affordable items and place values on the price of each item. This is totally 
different from younger college students who are obsessed with their interest on each item rather than price value.

Table 9. Role of demographic characteristics on price value factor of CSI $(n=2068)$

\begin{tabular}{|c|c|c|c|c|c|c|c|c|}
\hline \multirow[b]{2}{*}{ Variables } & \multicolumn{4}{|c|}{ Model 1} & \multicolumn{4}{|c|}{ Model 2} \\
\hline & B & SE & $\beta$ & $\mathbf{t}$ & B & SE & B & $\mathbf{t}$ \\
\hline Constant & 4.717 & .425 & - & $11.103 * * *$ & 4.934 & .443 & - & $11.145^{* * *}$ \\
\hline Gender & -.256 & .065 & -.087 & $-3.959 * * *$ & -.250 & .065 & -.085 & $-3.857 * * *$ \\
\hline Age & .052 & .018 & .062 & $2.835^{* *}$ & .050 & .018 & .060 & $2.721 * * *$ \\
\hline Ethnicity & -.022 & .047 & -.010 & -.475 & -.029 & .047 & -.014 & -.619 \\
\hline Place where the student was raised & .012 & .063 & .004 & .192 & -.005 & .064 & -.002 & -.078 \\
\hline Family size & & & & & -.024 & .014 & -.039 & -1.735 \\
\hline Household income & & & & & .000 & .000 & .004 & .197 \\
\hline $\mathbf{R}^{2}$ & & & .013 & & & & .014 & \\
\hline $\mathbf{F}$ & & & $5.029 * * *$ & & & & 1.560 & \\
\hline$\Delta \mathbf{R}^{2}$ & & & & & & & .001 & \\
\hline
\end{tabular}

Note: $\mathrm{B}=$ unstandardized beta; $\beta=$ standardized beta; $\mathrm{F}=\mathrm{f}$ statistics; $\mathrm{t}=\mathrm{t}$ statistics; $\mathrm{R}^{2}=$ variance;

$\Delta \mathrm{R}^{2}=$ change in variance $*=(\mathrm{p})<.05 ; * *=(\mathrm{p})<.01 ; * * *=(\mathrm{p})<.001$.

Despite not having a consensus finding from previous studies on the role of demographic variables towards consumer decision making styles, the present result is consistent with Mitchell and Walsh (2004); Hanzaee and Aghasibeig (2008); Mokhlis and Salleh (2009) on the role of gender towards brand fashion and perfectionistic consciousness. It is also consistent with Mishra (2010); Mokhlis and Salleh (2009); Fan and Xiao (1998) on age towards perfectionist, brand conscious, confused by over choice, hedonistic and price-value conscious factors of CDMS in Indian, Malaysian and Chinese studies respectively. It is notable that earlier studies did not investigate the role or differences between places where a consumer was raised, family size and household income. As such, this study offered an insight to the contributions of the aforementioned variables on CDMS factors.

\section{Conclusion and Recommendations}

This study has re-evaluated a section of the original CSI developed by Sproles and Kendall (1986) and the influence of two control measures which consisted of six demographic characteristics on each CSI factor. One of the key findings is the significant influence of gender, age, ethnicity, family size, household income and place where the student was raised on the factors of CSI. The study submits that Malaysian college students' shopping decision making styles are dependent on the above six demographic variables. Also, the study found seven factors which explained over $65 \%$ variance in CDMS among Malaysian college students with a section of the original CSI instrument. In addition, it is submitted that Malaysian college students' shopping decision is based on these factors (brand fashion, perfectionistic, hedonistic, habitual, novelty, confused by over choice and price-value consciousness). The difference in the number of CSI factors of this study and some western studies is because of the psychological and cultural differences between Malaysia and the West.

Based on the inferences, the researchers recommend that local and international marketers that have Malaysian students as their existing or potential customers should segment their market on the premise of brand fashion, perfectionistic, hedonistic, habitual, novelty, confused by over choice and price-value. As a result, it will help marketers to figure out and maintain the tastes and preferences of Malaysian college students through focused marketing strategies. Moreover, it will help consumer education perspective focusing on youth empowerment on the appropriate decision making styles. Further studies should be conducted to address the low reliability syndrome of Malaysian samples towards price-value factor as this study doubles the occurrence of low reliability in price-value among Malaysian respondents. There is also need to conduct a confirmatory factor analysis on these factors in order to reconfirm the items for each factor. Further, although Peterson (2001) identified a marginal likelihood of error within a measurement model when respondents are of homogeneous demographics, there is need to replicate this study with college students from remote regions of Malaysia. Hence, it will offer a comparative idea of college students' decision making styles to marketers.

\section{Acknowledgement}

It is acknowledged that the grant for this study is obtained from research univ. grants (RUG), Universiti Putra Malaysia. 


\section{References}

Anić, I. D., Ciunova Shuleska, A., \& Rajh, E. (2010). Decision-making styles of young- adult consumers in the $\begin{array}{llll}\text { Republic of } \quad \text { Macedonia. } & \text { Ekonomska istraživanja, } & \text { 4, }\end{array}$ http://dx.doi.org/10.1080/1331677X.2010.11517436

Ariffin, A. A. M, Ahmad, A. Hj, Ahmad, S., \& Ibrahim, A. (2008). Determining decision-making styles and demographic differences in selecting higher education services among Malaysians. International Journal of Business and Society, 9(1), 1-18.

Bae, S., Lam, E. T., \& Jackson, E. N. (2009). Development of the purchaser style inventory for sport products (PSISP). International Journal of Sport Management, 10, 151-168.

Bakewell, C., \& Mitchell, V. W. (2003). Generation Y female decision-making styles. International Journal of Retail and Distribution Management, 31(2), 95-106. http://dx.doi.org/10.1108/09590550310461994

Bakewell, C., \& Mitchell, V. W. (2004). Male consumer decision-making styles. International Review of Retail, Distribution and Consumer Research, 14(2), 223-240. http://dx.doi.org/10.1080/0959396042000178205

Bakewell, C., \& Mitchell, V. W. (2006). Male versus female consumer decision making. Journal of Business Research, 59, 1297-1300. http://dx.doi.org/10.1016/j.jbusres.2006.09.008

Cheryl, L., Rebekah, B., Charmine, E., \& Hartel, J. (2005). Cross-cultural differences in consumer decisionmaking styles. Cross Cultural Management: An International Journal, 12(3), 32-62. https://doi.org/10.1108/13527600510798060

Durvasula, S., Lysonski, S., \& Andrews, J. C. (1993). Cross-cultural generalizability of a scale for profiling consumers' decision-making styles", The Journal of Consumer Affairs, 27(1), 55-65. http://dx.doi.org/10.1111/j.1745-6606.1993.tb00737.x

Evans, K. R, Christiansen, T., \& Gill, J. D. (1996). The impact of social influence and role expectations onshopping center patronage intentions. Journal of the Academy of Marketing Science, 24(3), 208-218.

Fan, J. X., \& Xiao, J. J. (1998). Consumer decision-making styles of young adult Chinese. The Journal of Consumer Affairs, 32, 275-294. http://dx.doi.org/10.1111/j.1745-6606.1998.tb00410.x

Hafstrom, J. L., Chae, J. S., \& Chung, Y. S. (1992). Consumer decision-making styles: Comparison between United States and Korean young consumer. The Journal of Consumer Affairs, 26(1), 114-22. http://dx.doi.org/10.1111/j.1745-6606.1992.tb00020.x

Hair, J. F., Anderson, R. E., Tatham, R. L., \& Black, W. C, (1998). Multivariate Data Analysis. Prentice-Hall, New Jersey.

Hans. H. B., Nicola, E. S., \& Christine, B. (2006). Investigating the relationship between product involvement and consumer decision-making styles. Journal of Consumer Behavior, 5(4), 342-354. http://dx.doi.org/10.1002/cb.185

Hanzaee, K. H., \& Aghasibeig, S. (2008). Generation Y Female and Male Decision-Making Styles in Iran: Are they different? International Review of Retail, Distribution and Consumer Research, 18(5), 521-537. http://dx.doi.org/10.1080/09593960802573443

Hiu, A. S., Siu, N. Y., Wang, C. L., \& Chang, L. M. (2001). An investigation of decision-making styles of consumers in China. The Journal of Consumer Affairs, 35(2), 326-345. http://dx.doi.org/10.1111/j.1745-6606.2001.tb00117.x

Kaiser, H. F. (1974). An index of factorial simplicity. Psychometrika, 39, p. 31-36. Retrieved from https://pdfs.semanticscholar.org/f4f5/31ba422264ec4ff7fc09db8680f8299fc706.pdf

Kamaruddin, A. R., \& Kamaruddin. K. (2009). Malay culture and consumer decision-making styles: an investigation on religious and ethnic dimensions. Jurnal Kemanusiaan Bil.14, Dis. Retrieved from http://citeseerx.ist.psu.edu/viewdoc/ download?doi=10.1.1.938.9080\&rep=rep1\&type=pdf

Kavas, A., \& Yesilada, F. (2007). Decision Making Styles of Young Turkish Consumers. European Journal ofEconomics, Finance and Administrative Sciences, 9, 73-85.

Kumar, D. P., \& Sarangi, M. (2008). Sociocultural dimensions of consumer behavior on retail shopping: A specialfocus on textile consumption in Orissa. ICFAI University Journal of Consumer Behavior, 3(4), 7-23.

Madahi, A., Sukati, I., Mazhari, M. Y., \& Rashid, W. N. (2012). Consumer Decision Making Styles amongst Young Generation in Malaysia. European Journal of Social Sciences, 30(2), 263-275. 
Md Nor, O., Fon-Sim, O., \& Heng-Wai, W. (2008). Demographic and lifestyle profiles of ethnocentric and non-ethnocentric urban Malaysian consumers. Asian Journal of Business and Accounting, 5-26.

Mishra, A. A. (2010). Consumer Decision-Making Styles and Young-Adult Consumers: An Indian Exploration. İşletmeAraştırmaları Dergisi, $\quad 2(3), \quad 45-62 . \quad$ Retrieved $\quad$ from http://isarder.org/isardercom/2010vol2no3/c333.pdf

Mitchell, V. W., \& Bates, L. (1998). UK Consumer Decision-Making Styles. Journal of Marketing Management, 14(1/3), 199-225. http://dx.doi.org/10.1362/026725798784959345

Mitchell, V., \& Walsh, G. (2004). Gender Differences in German Consumer Decision-Making Styles. Journal of Consumer Behavior, 3(4), 331-346. http://dx.doi.org/10.1002/cb.146

Mokhlis, S. (2010). Religious Contrasts in Consumer Shopping Styles: A Factor Analytic Comparison. Journal of Business Studies Quarterly, 2(1), 52-64. Retrieved from http://jbsq.org/wp-content/uploads/2010/12/JBSQ 5E.pdf

Mokhlis, S., \& Salleh. H. S. (2009). Consumer Decision-Making Styles in Malaysia: An Exploratory Study of Gender Differences. European Journal of Social Sciences, 10(4), 574-584. Retrieved from https://pdfs.semanticscholar.org/3806/8d2000ec43375c7defd13cdfef1b126de065.pdf

Mukherjee, A., Satija, D., Goyal, T. M., Mantrala, M. K., \& Zou, S. (2012). Are Indian consumers brand conscious? Insights for global retailers. Asia Pacific Journal of Marketing and Logistics, 24, 482-499. http://dx.doi.org/10.1108/13555851211237920

Ng, S. W. (2005). Shopping and Buying Decision on Consumers' Decision-Making Styles: A Cross-Cultural Studyof the Youth Chinese and Macanese', In L. C. Huff and S. M. Smith ed. Conference Proceedings, Eleventh Cross-Cultural Research Conference, Puerto Rico, USA, 11-14 December.

Peterson, R. A. (2001). On the use of College Students in Social Science Research: Insights from a Second-OrderMeta-analysis. Journal of Consumer Research, 28(3), 450-461. https://doi.org/10.1086/323732

Sproles, G. B., \& Kendall, E. L. (1986). A methodology for profiling consumer decision-making styles. The Journal of Consumer Affairs, 20, 267-79. http://dx.doi.org/10.1111/j.1745-6606.1986.tb00382.x

Tai, S. H. (2005). Shopping styles of working Chinese females. Journal of Retailing and Consumer Services, 12, 191-203.

Walsh, G., Hennig-Thurau, T., Wayne-Mitchell, V., \& Wiedmann, K. (2001). Consumers' decision-making style as a basis for market segmentation. Journal of Targeting, Measurement and Analysis for Marketing, 10(2), 117-131. http://dx.doi.org/10.1057/palgrave.jt.5740039

Walsh, G., Mitchell, V. W., \& Thurau, T. H. (2001). German Consumer Decision-Making Styles. Journal of Consumer Affairs, 35(1), 73-95. http://dx.doi.org/10.1111/j.1745-6606.2001.tb00103.x

Wan Omar, M., Mohd Ali, M. N., Hussin, Z., \& Abdul Rahim, H. (2009). Decision orientations towards shopping and buying among young-adult Malays in The Universities. International Journal of Business and Management, 4(7), 26-30. http://dx.doi.org/10.5539/ijbm.v4n7p26

Wickliffe, V. P. (2004). Refinement and Re-Assessment of the Consumer Decision-Making Style Instrument. Journal of Retailing and Consumer Services, 11(1), 9-17. http://dx.doi.org/10.1016/S0969-6989(02)00057-7

\section{Copyrights}

Copyright for this article is retained by the author(s), with first publication rights granted to the journal.

This is an open-access article distributed under the terms and conditions of the Creative Commons Attribution license (http://creativecommons.org/licenses/by/4.0/). 